\title{
Evaluating bundles of interventions to prevent peat-fires in Indonesia
}

\section{Author names and affiliations}

Rachel Carmenta ${ }^{1}$, Jacob Phelps, Bambang Trihadmojo, David Gaveau, Mohammad Agus Salim, Aiora Zabala, University of Cambridge

${ }^{1}$ Corresponding author: Rachel Carmenta, Tyndall Centre and School of International Development, University of East Anglia, Norwich Research Park, Norwich, NR4 7TJ

\section{Present addresses}

Rachel Carmenta, Tyndall Centre and School of International Development, University of East Anglia, Norwich Research Park, Norwich, NR4 7TJ

Jacob Phelps, Lancaster Environment Centre, Lancaster University Bailrigg, Lancaster LA1 4YW, UK

Bambang Trihadmojo, Department of Sociology, Northwestern University, Evanston, IL, USA and The Nature Conservancy, Chicago, IL, USA

David Gaveau, Independent Scientist, SilviaMap, Bagadou Bas 46600 Martel, France Mohammad Agus Salim, Independent GIS \& Remote Sensing Specialist, SilviaMap, Situgede Bogor Barat 16115, Indonesia

Aiora Zabala, Department of Land Economy, University of Cambridge, CB3 9EP 


\begin{abstract}
The carbon-dense peatlands of Indonesia are a landscape of global importance undergoing rapid land-use change. Here, peat drained for agricultural expansion increases the risk of largescale uncontrolled fires. Several solutions to this complex environmental, humanitarian and economic crisis have been proposed, such as forest protection measures and agricultural support. However, numerous programmes have largely failed. Bundles of interventions are proposed as promising strategies in integrated approaches, but what policy interventions to combine and how to align such bundles to local conditions remains unclear. We evaluate the impact of two types of interventions and of their combinations, in reducing fire occurrence through driving behavioural change: incentives (i.e. rewards that are conditional on environmental performance), and deterrents (e.g. sanction, soliciting concerns for health). We look at the impact of these interventions in 10 villages with varying landscape and fire-risk contexts in Sumatra, Indonesia. A private-led implementation of a standardised programme allows us to study outcome variability through a natural experiment design. We conduct a systematic cross-case comparison to identify the most effective combinations of interventions, using two-step qualitative comparative analysis (QCA) and geospatial and socio-economic survey data $(\mathrm{n}=303)$. We analysed the combined influence of proximate conditions (interventions, e.g. fear of sanction) and remote ones (context; e.g. extent of peat soil) on fire outcomes. We show how, depending on the level of risk in the pre-existing context, certain bundles of interventions are needed to succeed. We found that, despite the programme being framed as rewards-based, people were not responding to the reward alone. Rather sanctions and soliciting concern appeared central to fire prevention, raising important equity implications. Our results contribute to the emerging global interest in peat fire mitigation, and the rapidly developing literature on PES performance.
\end{abstract}

\title{
Highlights
}

- Indonesian peat fires yield profound social, environmental and economic burdens

- We assess outcome determinants of a peat fire prevention program in Indonesia

- Two-step QCA identifies proximate and remote conditions of fire-free outcomes

- Effective combinations of interventions depend on landscape context

- Sanctions and concern awareness are most influential, while rewards are not

\section{Introduction}

Tropical forests are sites of dramatic land use change (Barlow et al., 2018), with peat-swamp forests particularly vulnerable to pressures arising across sectors and scales (Turetsky et al., 2015). These include agricultural expansion at forest frontiers, which is often associated with burning to clear land (Curtis et al., 2018). Resultant biophysical changes, combined with 
global warming, are causing increasingly frequent, uncontrolled mega-fire events in regions such as Indonesia and Brazil (Gaveau et al., 2017; Huijnen et al., 2016). These fires yield profound social, environmental and economic burdens (Crippa et al., 2016; Koplitz et al., 2016; Martin, 2019) — driving a growing need to identify which fire mitigation interventions are most successful, under different landscape conditions. We evaluate the outcomes of a fire prevention programme across 10 villages in Indonesia, to explore how bundles of interventions (including incentives) shape fire outcomes across different contexts.

Indonesian peatlands are globally important for their carbon stocks and provide a remnant forest block protecting Southeast Asian biodiversity (Husson et al., 2018; Turetsky et al., 2015). The expansion of oil palm and acacia plantations on peatlands that have been drained and often cleared using fire has generated significant local and regional burdens (Carmenta et al., 2017; Koplitz et al., 2016; Tan-Soo and Pattanayak, 2019). In drought years, intentional fires used to clear land can more easily escape and result in extensive uncontrolled peat fires (Cattau et al., 2016; Gaveau et al., 2014; Gaveau et al., 2017). The resultant toxic smoke (haze) is responsible for some of the worst sustained outdoor air pollution ever recorded, with atmospheric particulate matter concentrations exceeding those considered "extremely hazardous to health" by up to an order of magnitude (Wiggins et al., 2018; Wooster et al., 2018). In 2015, peat fires and haze on Sumatra became a humanitarian disaster responsible for an estimated 11,880-100,000 deaths, as well as closing down local and regional transport, education and industrial systems (Crippa et al., 2016; Koplitz et al., 2016). Carbon emissions from the peat fires were also considerable (11.3 million tons per day in September and October), exceeding those of the entire European Union (8.9 million tons) over the same period (Huijnen et al., 2016).

Fire mitigation is a pressing, but often controversial policy issue that is emblematic of the tensions between environment and development in peatland frontiers (Carmenta et al., 2017; Goldstein, 2016; Manzo et al., 2019; Sloan et al., 2017). Proposed mitigation efforts are diverse; some proponents have argued for continue business as usual development alongside fire risk measures, while others have proposed a transformation of land uses on peatlands and question, and yet others consider any development on peatlands inherently unsustainable (Carmenta et al., 2017; Evers et al., 2017; Wijedasa et al., 2017). These include dozens of overlapping mitigation programmes, including those by the Government of Indonesia (e.g. Peatland Restoration Agency), development banks (e.g. IFAD's Sustainable Peatland Management) and agro-industrial companies (e.g. Fire Free Alliance (FFA)) (Carmenta et al., 2017; Jefferson et al., 2020). These involve enforcement-based approaches, integrated conservation and development projects (ICDP), forest and landscape restoration (e.g., Bonn challenge, Horizon 2020, Peatland Restoration Agency) and payments for ecosystem services (PES) schemes.

Research to assess the impacts of these diverse environmental programmes is heterogeneous and largely inconclusive (e.g. Duchelle et al., 2018; Oldekop et al., 2016). Notably, evaluations rarely assess outcomes and tend to overlook that fire mitigation efforts are often comprised of bundles of complimentary interventions. Further, programme success is often defined by the "interplay between context, design and implementation" (Wunder et al., 2018 
pp. 145). Indeed, interventions involve multiple interacting factors, where interaction is rarely linear, involves feedbacks (Wunder et al., 2018), and is heavily shaped by context (Blom et al., 2010; Medin et al., 2006; Ostrom et al., 2007). Faced with such complexity, there is a need for better understanding of how outcomes are shaped by bundles of interventions and contextual landscape factors (Travers et al., 2016).

We compared 10 Indonesian villages that participated in the Fire Free Village (FFV) programme, a PES scheme operationalised by a pulp and paper company to incentivise smallscale farmers living in the communities adjacent to their acacia tree concession areas to reduce fire use and reduce the prevalence of uncontrolled fires (APRIL, 2017; Gaveau et al., 2017). Despite experiencing the same specific intervention bundles, the 10 sites resulted in different fire-related outcomes (i.e. some sites experienced no fire, some experienced small fires, and some experienced status-quo fire occurrence from no fire, to continued fire occurrence). We sought to determine how outcomes were shaped by sets of "remote conditions" that represented the contextual attributes of 10 village sites, and "proximate conditions" that represented the specific interventions of the FFV programme. This involved a two-step qualitative comparative analysis to identify the role of conditions and of their combinations, on FFV performance, where fire-free is the outcome associated with the success of the PES programme.

The FFV case provides a natural experiment for studying the design of environmental programmes. In its design, the FFV seems to exemplify an 'idealised' PES design connecting environmental service providers with buyers (agro-industry) in a voluntary arrangement where incentives are conditional (i.e. upon verified delivery of the service) (Wunder, 2005; Wunder et al., 2018). Within the FFV these PES design attributes are delivered alongside a standardized bundle of interventions that include deterrents (e.g. sanctions, soliciting concerns for health). In practice, combinations of interventions are likely necessary and require an understanding of how contexts and combinations of interventions impact outcomes. Further, the FFV offers a unique opportunity to analyse and compare performing and non-performing PES within a natural field experiment (cf. Grima et al., 2016). The scheme is also important in of itself. While many fire mitigation interventions are considered controversial in Indonesia, efforts that involve support for small-scale farmers to pursue firefree livelihoods is the least controversial policy option (Carmenta et al., 2017). The Indonesian government also recently announced plans to scale-up to over 700 villages across fire-affected regions (Sloan et al., 2017).

\section{Material and methods}

\subsection{Qualitative comparative analysis (QCA)}

Qualitative comparative analysis (QCA) is a structured approach to compare cases, where case characteristics do not lend themselves to large-sample statistical analysis, and where the depth of case study approaches is sought to be maintained. It facilitates systematic 
comparative case understanding and generalization, while retaining the nuance and context specificity that a standard statistical analysis would lose (Ragin, 1987; Rihoux, 2003). QCA is an 'intermediate-n' approach (typically with 5 to 50 cases) either through design, or because a limited number of cases (observations) exist (Sehring et al., 2013). It is used to deduce causal pathways and identify combinations of conditions (factors or independent variables) that result in particular outcomes (dependent variable). The approach has been applied to understand a diverse environmental governance contexts, including conflicts about renewable resources (Ide, 2015), the relationship between multi-level governance, local autonomy and biodiversity conservation (Basurto, 2013) and to identify the enabling conditions for REDD+ policies for reducing emissions from deforestation and degradation (Brockhaus et al., 2017).

QCA is rooted in comparative sociology and politics (Ragin, 1987) and based on set theory (i.e. distinct from correlational theory), in which outcomes are understood to be determined by whether cases belong to particular sets (Arts and de Koning, 2017). Whether cases are members of a set is defined as the presence or absence of the conditions in that case. The cases, and whether they demonstrate or lack each condition (denoted with upper and lower case respectively), are summarised in so-called truth tables. Conditions are pre-identified by researchers, who also establish a threshold that determines presence (Arts and de Koning, 2017). QCA analysis focuses on the combinations of conditions (in QCA, these are called 'configurations' of conditions) that result in a specific outcome (Marx et al., 2014), rather than on the contribution of individual conditions in isolation. QCA assumes that outcomes can occur through multiple pathways and combinations, and aims to identify conjunctural causation (Schneider and Wagemann, 2006). Different configurations of conditions can result in the same outcome (equifinality), and the effect of a condition can change depending on the configuration and context (Rihoux, 2003). QCA is therefore particularly useful for understanding social-ecological systems in which multiple interacting factors contribute to outcomes.

QCA analysis uses boolean algebra to minimise the cases to a number of possible configurations of conditions that are sufficient to achieve the outcome. This approach facilitates replicability and hypothesis falsification. After this minimisation process, the researchers assess the role of each condition in causality (Schneider and Wagemann, 2012). To do so, conditions are labelled as sufficient (if present, they generate the outcome) or necessary (they are present when we observe the outcome, but alone are insufficient to generate it, so we may see the condition without the outcome) (Schneider and Wagemann, 2006). A condition is regarded as irrelevant if two configurations that generate the outcome are the same, except that a given condition is present in one and not the other configuration (Arts and de Koning, 2017 pp., 319). Finally, the set theory approach of QCA can identify complex causal pathways, including pathways in which a condition is neither necessary, nor sufficient but rather operates in conjunctural causation with other conditions, or has a distinct context-dependent effect (Schneider and Wagemann, 2006).

There are a number of attributes that make QCA appropriate to this study: the limited number of cases available (i.e. the 10 villages within the FFV programme); the comparability of case 
contexts (see below); the cases and salient conditions were numerous enough to warrant structured analysis, and the cases presented different outcomes.

\subsubsection{Two-step QCA}

Two-step QCA can serve to identify the relative contributions of a subset of variables identified as important to shaping processes of environmental change in a specific study context (Table 1; Cattau et al., 2016; Defries et al., 2010; Dennis et al., 2005; Geist and Lambin, 2002). These variables were divided in to remote and proximate conditions. Remote conditions are those structural or contextual factors that shape environmental change but tend to be more stable over time (e.g. soil type or livelihoods). In contrast proximate conditions tend to be more changeable along shorter time lines, including as a result of policy intervention (e.g. issuing sanctions) (Schneider and Wagemann, 2006). Remote conditions interact with proximate conditions where they enable or constrain environmental outcomes.

The two-step version of QCA analyses remote conditions separately from the proximate ones and then assesses combinations between these two sets of configurations (one-step QCA analyses all the conditions together in a single-step). Two-step QCA assumes that the context (i.e. remote conditions) defines outcomes in combination with the proximate conditions. Initially, truth tables of presence or absence are produced for the remote conditions. From these, the contradictory outcomes are retained for the next step. Contradictory outcomes occur when the same combination of conditions results in both success and failure cases. The second step of the analysis allows researchers to determine the context-specific role of proximate conditions (Schneider and Wagemann, 2006). The two-step QCA is designed to resolve case contradictions in remote configurations; results that appear inconclusive by examining context alone (Schneider and Wagemann, 2006). By adding the proximate conditions to the analysis (elements of the FFV programme), researchers can identify how they interact with the context (i.e. remote conditions) to give particular outcomes. In our twostep QCA approach, we apply the crisp set variant, which is preferable to the fuzzy-set alternative for small $\mathrm{n}$ such as ours because it avoids the prevalence of logical remainders (Sehring et al., 2013). In crisp set QCA the binary Boolean approach $(0,1)$ is used, in which presence is determined by absolute membership (or its absence) and specified using determined thresholds (Korhonen-Kurki et al., 2013).

Two-step QCA is particularly suited for small samples, where the probability of some theoretically possible configurations not being observed is higher. In QCA, these unobserved but possible configurations, are called logical remainders. Two-step QCA reduces their probability by reducing the number of possible combinations of conditions (Schneider and Wagemann, 2006).

\subsection{Study sites}

\subsubsection{Fire history and land use change in Riau}

The carbon-dense peat forest landscapes of Riau Province (Sumatra, Indonesia, Figure 1) were once considered marginal lands (Persoon and Simarmata, 2014). Around 1990, they 
became the primary target of large industrial-scale pulpwood plantations, mainly of fastgrowing Acacia crassicarpa (Gaveau et al., 2014; Miettinen et al., 2016). Later, oil palm plantations dominated and, over the last three decades, peat-swamp forests in Riau have been drained and cleared on an industrial scale (Miettinen et al., 2016). Related to these dramatic land use changes are extensive anthropogenic peat fires that have marred the region, including Indonesia's ASEAN neighbours, with air pollution (Gaveau et al., 2014). The paleo record confirms that the contemporary incidence of peat fires is unprecedented in the ecological history of the peatlands (Cole et al., 2019; Hapsari et al., 2018). Peat fires are driven by recent forms of anthropogenic disturbance, created by new and diverse actors in increasingly teleconnected frontier landscapes (Adrianto et al., 2020; Cattau et al., 2016; Gaveau et al., 2014; Gaveau et al., 2017; Jelsma et al., 2017).

Resource and fire management in Riau are challenged by overlapping land claims among national and provincial governments, companies, investors and communities, often with deep political and financial interests in lucrative oil palm production, alongside weak law enforcement (Dennis et al., 2005; Gaveau et al., 2017; Varkkey, 2016) . Following the recent devastating fire events of 2013, 2014 and 2015, a renewed impetus of initiatives are underway in Riau province to mitigate future fire events (Tacconi, 2016; Wooster et al., 2018). These have included efforts to protect peatlands from fires through re-flooding and through moratoriums on new agricultural expansion, and the development of new multistakeholder landscape governance approaches (Jefferson et al., 2020). For example, Fire Protection Associations (FPAs, or 'Klaster' in Indonesia) are formal legal entities of land users (state, community and private) that serve to address fire risk at a landscape level (ranging in size from 800000 ha to 4 million ha). They employ collaborative stakeholder engagement, resources sharing and interventions that deliver multiple benefits (e.g. agriculture, health) as part of a strategy to reduce fire risks.

\subsubsection{The Fire Free Village Private Sector PES}

The Fire Free Village (FFV) programme was started in 2014 by an industrial scale pulp and paper agri-business, to protect their plantation from fires believed to have been started on the lands adjoining their sites. Implementation was intentionally standardized across communities, with 5 main activities that include incentives and deterrents:

- Incentive: Agricultural support, including the disbursement of seeds and fertilizers, and the provision of machinery to open new land without fire. However, in practice the unclear land tenure status of some villagers land meant that the mechanical land clearance component was used less frequently than anticipated.

- Incentive: An annual conditional incentive to reward communities in the form of funding for a community project. The incentive was provided to support community infrastructure projects, as selected by the communities themselves. Its delivery was conditional on outcomes: the full payment involved a project equivalent to 100 million Indonesian Rupiah (approx. US 7,000 [March 2019]), if the external assessment indicated that the community had zero local fires in the participating year. Half-payments were granted if fire activity was detected affecting $<1$ hectare, and 
zero incentive was provided for burning detected at $>1$ hectare. The FFV did not differentiate payments, and all villages received the same regardless of favourable or unfavourable underlying conditions (e.g. size of the area, drought incidence, clarity over local tenure). The program has issued rewards yearly since 2015 .

- Deterrent: Air quality monitoring, which involved the installation of <PM10 air quality monitors at each site.

- Deterrent: Awareness raising focussed on highlighting the dangers of wildfires to health, through educational campaigns, forums and discussions.

- Deterrent: Hiring a local fire warden to raise awareness, attend meetings, and engage residents.

While the FFV is a private sector-led initiative, it operates in partnership with government actors. Company representatives are accompanied by local State representatives (e.g. army officials and police officers) when the FFV scheme is introduced in communities. Although not officially listed as one of the standardized activities of the FFV, this process is intended to support fire-free outcomes through raising awareness of the illegality of peat fires and of the potential associated sanctions. It potentially blurs participants' understanding of the institutions mandating the programme.

The FFV has been implemented in the 10 villages in Riau Province, Sumatra where this study is based (Fig. 1). The villages in the study were identified by the implementers as potential fire sources located around their agricultural concessions, and had a maximum difference of 1 year between FFV implementation start dates. The villages were comprised predominantly of Malay, Javanese and Batak small-scale farmers that are employed in daily labour in oil palm plantations and own their own oil palm plots. Households also owned other plantation crops (e.g. rubber), food crops and fishing. The villages varied in several aspects that are relevant to their FFV performance, including the extent of peat or mineral soil, past experiences with fire, proportion of land planted, and the livelihood diversity of residents. These informed the conditions that are the basis of the QCA analysis (see section 2.3). 

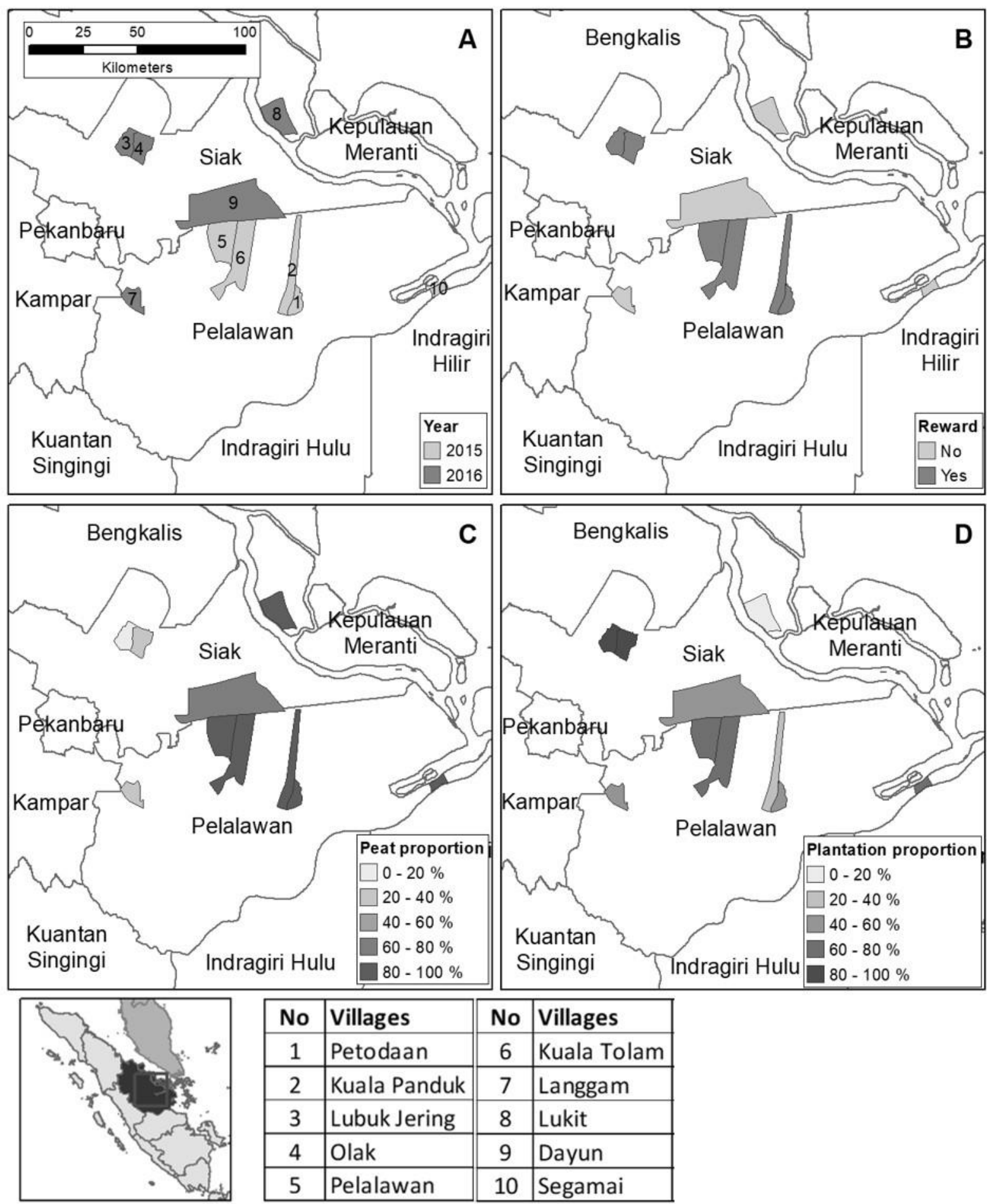

\begin{tabular}{|c|l||c|l|}
\hline No & Villages & No & Villages \\
\hline 1 & Petodaan & 6 & Kuala Tolam \\
\hline 2 & Kuala Panduk & 7 & Langgam \\
\hline 3 & Lubuk Jering & 8 & Lukit \\
\hline 4 & Olak & 9 & Dayun \\
\hline 5 & Pelalawan & 10 & Segamai \\
\hline
\end{tabular}

Figure 1. Map of the study region in Riau, Sumatra (see Inset). (A) Administrative boundaries of all ten Fire Free Villages studied. Numbers from 1 to 10 indicate the name of the village and colour indicates the year the program started.. (B) Villages which received the fire-free reward or not (in 2016). Colour gradient represents (C) the proportion of the village area covered with peat land and (D) the proportion of the village area planted with either acacia or oil palm.

\subsection{Conditions for fire-free outcomes: remote and proximate}

The outcome in our analysis was binomial: (1) the FFV payment (half- and full-payment) was issued to a village for either achieving a fire-free outcome or a total burnt land area <2ha 
within the village in the preceding year, or (0) FFV payment was withheld because the programme detected $>2$ ha total burnt land in the preceding year. Burnt area was evaluated by FFV Crew Leaders using monthly helicopter surveillance and then ground truthing with burn scar mapping. FFV payments therefore served as a proxy for fire extent and, indirectly, for deforestation and land use change in the given year.

We explored the outcome in relation to 3 remote conditions and 3 proximate conditions (Table 1) selected based on: i) the case knowledge of experts, including the researchers and the FFV managers; ii) the FFV operational aspects, iii) literature review, and iv) geospatial data (Table 2). We selected conditions that were conceptually relevant and had a sufficient degree of variability among villages. "Remote" conditions were variables that likely shaped FFV outcomes and contributed to low or high risk fire contexts but were beyond the influence of the FFV. "Proximate" conditions were those within the immediate control of the FFV programme. Although agricultural support was a feature of the FFV, and has great potential to influence outcomes (Angelsen and Kaimowitz, 2001; Phalan et al., 2016) we did not include it as a condition because very few households accessed this package, according to our survey. For a full elaboration of the six conditions used in the analysis see Supplementary Table 1.

Table 1. The remote and proximate conditions. The justification for the remote and proximate condition used in the two-step QCA to assess what conditions lead to fire-free outcomes within the Fire Free Village programme. Full justification can be found in Supplementary Table 1.

\begin{tabular}{|c|c|}
\hline Condition & Justification \\
\hline \multicolumn{2}{|l|}{ Remote conditions } \\
\hline Extent of area planted (PLA) & $\begin{array}{l}\text { - Fire is used to open land for production } \\
\text { - Fire frequency should drop as the frontier is established }\end{array}$ \\
\hline $\begin{array}{l}\text { Percentage of peatland } \\
(\text { PEA })^{1}\end{array}$ & $\begin{array}{l}\text { - } \quad \text { Peat soils are uniquely susceptible to fire } \\
\text { - } \quad \text { Peat soils are a target of contemporary land use change } \\
\text { - } \quad \text { Fire-fighting on peat is particularly challenging }\end{array}$ \\
\hline Livelihood diversity (LIV) & $\begin{array}{l}\text { Discontinuation of fire-based land clearance for fire } \\
\text { dependent households is a constraint } \\
\text { - Households with more diverse livelihood portfolios are } \\
\text { more resilient and more innovative }\end{array}$ \\
\hline \multicolumn{2}{|l|}{ Proximate conditions } \\
\hline $\begin{array}{l}\text { Satisfaction of Rewards } \\
\text { (REW) }\end{array}$ & $\begin{array}{l}\text { - Rewards can incentivize compliance } \\
\text { - The reward must be sufficient in order to generate uptake } \\
\text { by resource suppliers } \\
\text { - The reward is undifferentiated and in-kind leaving } \\
\text { potential for variable satisfaction among residents }\end{array}$ \\
\hline
\end{tabular}

\footnotetext{
${ }^{1}$ Depth of peat is an important variable when considering the carbon related impacts of converting peat landscapes to agriculture, but is not of primary relevance to fire contagion (i.e. dry peat is flammable regardless of whether it is deep or shallow). There is considerable uncertainty regarding peat depth within the scientific community, which also problematizes using this variable (Goldstein, 2016).
} 


\begin{tabular}{|l|l|}
\hline Sanctions for burning (SAN) & $\begin{array}{l}\text { - } \\
\text { - Sanctions can be powerful deterrents } \\
\text { Sanctions when combined with rewards are thought to be } \\
\text { a powerful intervention in the governance tool-kit }\end{array}$ \\
\hline Health deterrent (HEA) & $\begin{array}{l}\text { The health burden of the peat fires is considerable and } \\
\text { prioritized by diverse stakeholder groups }\end{array}$ \\
& $\begin{array}{l}\text { Perceptions of health risk have potential to relate to fire- } \\
\text { free practices and could be especially influential when } \\
\text { constraints to fire-free options are relieved }\end{array}$ \\
\hline
\end{tabular}

\subsection{Data sources and thresholds}

We collected data on the conditions through desk- and field-based data collection.

\subsubsection{Household surveys}

We conducted at least 30 household surveys in each of the 10 villages within the FFV (31 and 32 in two villages) (Figure 1) yielding 303 surveys and representing $2-26 \%$ of the households within each village. We used a random sampling design and considered the sample representative at the village level (see Supplementary Information 1). The survey captured household data on socio-economic status and demographics; land uses; on and off farm livelihood strategies; perceptions about peat fire and fire use, and about the FFV. Survey items were translated from English to Indonesian and piloted in the field to test for meaning and modified accordingly. Interviews were conducted from November to December 2016 by a field team. The field coordinator contributed to the design of the survey and the full team received training on the survey in the field, before piloting and embarking on data collection.

Specific questions on household fire use were omitted from the survey, to reduce the sensitivity of the instrument and avoid both conflicts and social desirability. Participant information sheets listing the aims and activities of the project were shared, the anonymity and confidentially of participating was highlighted, and oral consent obtained from each respondent.

2.4.2. GIS dataThe administrative boundaries of the FFV villages were digitized based on a map provided by the pulp and paper company (Asia Pacific Resources International Limited, APRIL) that mandates the Fire Free Village (FFV) programme. We quantified the percentage peat land within a village using the peatland map of the Indonesian Ministry of Agriculture, which serves as a proxy for actual peatland extent. We used a map of oil palm and acacia plantations (representing the situation in 2012 created by Dinas Kehutanan Riau (based on Landsat imagery and field surveys) to assess the percentage of planted lands within villages, and fire hotspot data (TERRA and AQUA satellites), from NASA-FIRMS fire map to explore the relationship between fire density (number of fire hotspots per $\mathrm{km}^{2}$ ) and our other potential conditions in a correlation matrix (following which we excluded fire density). 


\subsubsection{Defining thresholds for conditions}

For each of the 6 conditions, we established thresholds to determine their presence (1) or absence (0). Thresholds were based on evaluation of a number of sources, including field observations, statistical inference of survey data and remote sensing observations (Table 2). When the statistical average of the ten villages was consistent with these other sources, we kept this value to determine thresholds; villages above the average were associated with presence, and those below the average with absence (Table 2). However, where evidence suggested that the average was not a reasonable threshold (i.e. for PEA, PLA, SAN, REW), thresholds were informed through triangulation of the additional sources. Full values for each condition per village are given in Supplementary Table 2.

Table 2. Description of the conditions. Description of the conditions, including three remote and three proximate conditions used in the qualitative comparative analysis. Thresholds, sources (Literature review, Expert opinion including FFV implementing staff and researchers working on peat fire, FFV publications) and the evaluation used to define the thresholds are given for each condition.

\begin{tabular}{|c|c|c|c|c|c|}
\hline Condition & $\begin{array}{l}\text { Informed } \\
\text { by }\end{array}$ & Data source & Categories & Evaluation & $\begin{array}{l}\text { Threshold } \\
\text { Mean value }\end{array}$ \\
\hline \multicolumn{6}{|c|}{ Remote Conditions } \\
\hline $\begin{array}{l}\text { Percentage } \\
\text { of peatland } \\
\text { (PEA) }\end{array}$ & $\begin{array}{l}\text { Literature } \\
\text { Expert }\end{array}$ & $\begin{array}{l}\text { Geospatial } \\
\text { dataset. } \\
\text { Sumatra Peat } \\
\text { Land } \\
\text { Distribution } \\
\text { Map, } \\
1: 250,000 \\
\text { Scale' } \\
\text { published by } \\
\text { Indonesia } \\
\text { Ministry of } \\
\text { Agriculture } \\
\text { in 2011. }\end{array}$ & Soil type: peat, mineral. & $\begin{array}{l}\% \text { peat soil within } \\
\text { the boundary of the } \\
\text { FFV }\end{array}$ & $\begin{array}{l}\text { Villages } \\
\text { with a } \\
\text { fraction of } \\
0.7 \text { or more } \\
\text { equal } 1\end{array}$ \\
\hline $\begin{array}{l}\text { Livelihood } \\
\text { diversity } \\
\text { (LIV) }\end{array}$ & $\begin{array}{l}\text { Literature } \\
\text { Expert }\end{array}$ & $\begin{array}{l}\text { Household } \\
\text { survey. }\end{array}$ & $\begin{array}{l}\text { Categories included: } \\
\text { fishing or aquaculture, } \\
\text { livestock, non-timber } \\
\text { forest products, poultry, } \\
\text { oil palm, rubber, food } \\
\text { crops, swallow, or others. }\end{array}$ & $\begin{array}{l}\text { Average number of } \\
\text { activities engaged in } \\
\text { on average by the } \\
\text { community } \\
\text { households. }\end{array}$ & $\begin{array}{l}\text { Villages } \\
\text { with } 7 \\
\text { activities or } \\
\text { more equal } \\
1\end{array}$ \\
\hline $\begin{array}{l}\text { Percentage } \\
\text { of planted } \\
\text { land (PLA) }\end{array}$ & Literature & $\begin{array}{l}\text { Geospatial } \\
\text { dataset. } \\
\text { Land cover } \\
\text { map (2012) } \\
\text { generated by } \\
\text { Dinas } \\
\text { Kehutanan } \\
\text { Riau. }\end{array}$ & $\begin{array}{l}\text { Planted with: acacia, oil } \\
\text { palm }\end{array}$ & $\begin{array}{l}\% \text { planted land } \\
\text { within the boundary } \\
\text { of the FFV }\end{array}$ & $\begin{array}{l}\text { Villages } \\
\text { with } 75 \% \text { of } \\
\text { the area } \\
\text { planted } \\
\text { equal } 1\end{array}$ \\
\hline \multicolumn{6}{|c|}{ Proximate Conditions } \\
\hline $\begin{array}{l}\text { Reward } \\
\text { satisfaction } \\
(\text { REW })\left(^{*} \text {, }\right. \\
\text { ) }\end{array}$ & $\begin{array}{l}\text { Expert } \\
\text { FFV } \\
\text { material }\end{array}$ & $\begin{array}{l}\text { Household } \\
\text { survey. }\end{array}$ & $\begin{array}{l}\text { "How satisfied are you } \\
\text { with the reward from } \\
\text { FFV" (3) } \\
\text { "I think the choice of } \\
\text { reward for FFV can make }\end{array}$ & $\begin{array}{l}\text { Overall level of } \\
\text { satisfaction with the } \\
\text { FFV reward, defined } \\
\text { as above, or below } \\
\text { the average }\end{array}$ & $\begin{array}{l}\text { Above } 0.80 \\
\text { equals } 1\end{array}$ \\
\hline
\end{tabular}




\begin{tabular}{|c|c|c|c|c|c|}
\hline & & & $\begin{array}{l}\text { people really stop burning } \\
\text { land" (3) } \\
\text { "I want my village to get } \\
\text { reward" (5) } \\
\text { "People's lives are better } \\
\text { since FFV" (3) ( ) }\end{array}$ & & \\
\hline $\begin{array}{l}\text { Sanctions } \\
\text { for burning } \\
(\text { SAN) } \\
(*, f)\end{array}$ & $\begin{array}{l}\text { Expert } \\
\text { Literature } \\
\text { FFV } \\
\text { material }\end{array}$ & $\begin{array}{l}\text { Household } \\
\text { survey. }\end{array}$ & $\begin{array}{l}\text { "I'm afraid to be arrested } \\
\text { by police" (5) } \\
\text { "I'm afraid to get fined" } \\
\text { (5) }\end{array}$ & $\begin{array}{l}\text { Overall level of } \\
\text { awareness and } \\
\text { concern over the } \\
\text { sanction of the FFV } \\
\text { and fire use. Defined } \\
\text { as above or below } \\
\text { the average. }\end{array}$ & $\begin{array}{l}\text { Above } 0.45 \\
\text { equals } 1\end{array}$ \\
\hline $\begin{array}{l}\text { Health } \\
\text { awareness } \\
(\text { HEA })(*)\end{array}$ & Literature & $\begin{array}{l}\text { Household } \\
\text { survey. }\end{array}$ & $\begin{array}{l}\text { "Haze from the land fire } \\
\text { affects my health" (3) }\end{array}$ & $\begin{array}{l}\text { Overall level of } \\
\text { concern about the } \\
\text { negative impacts of } \\
\text { fire (health, social } \\
\text { and general). } \\
\text { Defined as above or } \\
\text { below the average. }\end{array}$ & $\begin{array}{l}\text { Above } 0.53 \\
\text { equals } 1\end{array}$ \\
\hline
\end{tabular}

(*) This is a composite indicator based on responses to the Likert-scale questions listed in 'Categories and percentage'. For each question, the number in parenthesis is the number of ordered categories in the response scale. For each question, we calculated the average per village and standardised it to a range of 0 to 1 (using the upper theoretical limit of the highest scale point, in parenthesis). We used the resulting value to calculate the mean of the composite indicator, which also has a theoretical range of 0 to 1. ( ) For Reward Satisfaction, where respondents indicated they had not heard of the reward, this was coded as such. ( $₹$ ) For Sanction - this was phrased in general terms, and not specifically tied to the commencement of the FFV.

\section{Results}

The first step of the two-step QCA indicates which of the remote conditions contribute to determining the outcome of the FFV programme. Following Boolean script, capitalization denotes presence, while lower case denotes absence. We did not interpret the logical remainders (i.e. configurations that could theoretically exist but were not present in our data set) in order to focus on the insights afforded by the empirical data alone (following Korhonen-Kurki et al., 2013; Schneider and Wagemann, 2012).

\subsection{First step: identifying the remote conditions of FFV}

There were 4 combinations of remote conditions in our sample (Table 2) that led to positive outcomes (in two villages) or contradictory outcomes (i.e. where the same set of conditions resulted in both a failure and a success -in two villages): PLA*PEA*liv (KT,Pela) + PLA*pea*LIV (LJ,Olak); pla*PEA*LIV (KP) + pla*PEA*liv (Peto). These four configurations can be minimized with boolean algebra to the configurations that enable the outcome: pla*PEA (KP, Peto $)+$ PEA*liv (KT, Pela, Peto $)+$ PLA*pea*LIV (LJ, Olak). Multiple combinations of remote conditions were associated with the fire-free outcome of the FFV. Indicating that no single combination of contextual conditions leads to performance, rather FFV implementation can reduce fire prevalence in a range of different contexts. Further, no single remote condition was necessary or sufficient for determining the performance of the FFV, highlighting the importance of conjunctural causation - that is the combined effect of combinations of conditions. The prevalence of planted area within the boundaries of FFV 
programmes was associated with programme success in most cases (4 of 6), however, the importance of this condition was not retained in the minimization process.

Successful cases existed even in high risk contexts (see section 2.3), such as in villages with large extents of unplanted land (e.g., KP village), high proportions of peat soil and limited livelihood diversity (e.g., Peto village). These cases with high risk contexts indicate that the FFV programme can mitigate fires, even in the high risk contexts that we identified. Successful cases were also found in relatively low risk contexts (e.g., LJ and Olak), where most land was already planted into permanent plantations creating little need for fire-based land clearance, where fire-prone peat soil was sparse and where livelihood diversity was high.

The data demonstrated contradictory cases where the same combination of remote conditions led to both FFV success and failure (Table 2). Two combinations resulted in contradictory outcomes. These were the cases of absence of planting and presence of peat, regardless of livelihood diversity (rows 3 and 4 in Table 2).

Each of the two villages where livelihoods were diverse (KP and Seg.) had a different outcome. From the three villages with low livelihood diversity, two had negative outcomes (Dayun and Lukit) and one had positive ones (Peto.).

Table. 3. Truth table of remote conditions in villages of the Fire Free Village programme. Shading denotes the level of fire risk associated with the conditions, relatively high risk (grey shade), relatively low risk (no shade). Outcome refers to reward status in 2016 where present (1) and absent (0).

\begin{tabular}{|l|l|l|l|l|}
\hline PLA & PEA & LIV & Outcome & Cases \\
\hline 1 & $\mathbf{1}$ & $\mathbf{0}$ & 1 & KT, Pela. \\
\hline 1 & 0 & 1 & 1 & LJ, Olak \\
\hline $\mathbf{0}$ & $\mathbf{1}$ & 1 & C & KP (1), Seg. (0) \\
\hline $\mathbf{0}$ & $\mathbf{1}$ & $\mathbf{0}$ & C & Dayun (0), Lukit (0), Peto (1) \\
\hline $\mathbf{0}$ & 0 & $\mathbf{0}$ & 0 & Lang. \\
\hline
\end{tabular}

Notes: 1: present, 0: absent, C: contradictory result. Three out of 8 possible configurations do not appear in the sample (i.e. pla*pea*LIV; PLA*pea*liv; PLA*PEA*LIV).

Only one configuration, found in one case, led to a negative outcome: pla*pea*liv. This case (Langam) indicates that unplanted land and few livelihood options can lead to FFV failure, even when fire prone peat soils are not prevalent.

Table. 4. Truth table for both remote and proximate conditions across all villages in the Fire Free Village programme.

\begin{tabular}{|l|l|l|l|l|l|l|l|}
\hline \multirow{2}{*}{ Cases } & \multicolumn{4}{|l|}{ Remote } & \multicolumn{2}{l|}{ Proximate } & \multirow{2}{*}{ Outcome } \\
\cline { 2 - 8 } & PLA & PEA & LIV & REW & SAN & HEA & \\
\hline Peto & 0 & 1 & 0 & 0 & 1 & 1 & 1 \\
\hline KP & 0 & 1 & 1 & 1 & 0 & 1 & 1 \\
\hline
\end{tabular}




\begin{tabular}{|l|l|l|l|l|l|l|l|}
\hline LJ & 1 & 0 & 1 & 0 & 1 & 1 & 1 \\
\hline Olak & 1 & 0 & 1 & 1 & 1 & 0 & 1 \\
\hline Pela. & 1 & 1 & 0 & 0 & 1 & 1 & 1 \\
\hline KT & 1 & 1 & 0 & 1 & 1 & 1 & 1 \\
\hline Lang. & 0 & 0 & 0 & 0 & 1 & 0 & 0 \\
\hline Lukit & 0 & 1 & 0 & 0 & 0 & 1 & 0 \\
\hline Dayun & 0 & 1 & 0 & 1 & 0 & 1 & 0 \\
\hline Seg & 0 & 1 & 1 & 0 & 1 & 0 & 0 \\
\hline
\end{tabular}

\subsubsection{Second step: identifying the role of proximate conditions in given contexts}

The second step of the two-step QCA identified which proximate conditions combined with the three enabling remote conditions to generate outcomes (Table 3, Figure 2). Overall, in low risk contexts our results suggest that a single intervention appears to be enough to generate fire-free outcomes (Table 4). However, in high risk contexts (Table 5), combinations of proximate conditions, namely of health concerns and fear of sanctions, were necessary to mitigate fire.

The first combination of remote conditions that enabled the outcome (PLA*pea*LIV) is characterised as low risk and it was associated with two configurations of proximate conditions (Table 4): PLA*pea*LIV*rew*SAN*HEA + PLA*pea*LIV*REW*SAN*hea. These can be simplified to: PLA*pea*LIV*SAN.

This finding indicates that in low risk landscape contexts, such as when large extents of land are already planted, there is little peat soil and livelihoods are highly diverse, fear of sanction alone was enough to generate fire-free outcomes.

Table 5. Truth table for the proximate conditions and PLA*pea*LIV - a low fire risk context with fire-free outcomes.

\begin{tabular}{|l|l|l|l|l|l|}
\hline \multirow{2}{*}{ Cases } & $\begin{array}{l}\text { Remote conditions } \\
\text { PLA*pea*LIV }\end{array}$ & \multicolumn{3}{|l|}{ Proximate } & \multirow{2}{*}{ Outcome } \\
\cline { 3 - 6 } & & REW & SAN & HEA & \\
\hline LJ & 1 & 0 & 1 & 1 & 1 \\
\hline Olak & 1 & 1 & 1 & 0 & 1 \\
\hline
\end{tabular}

The second remote context that enabled fire-free outcomes (PEA*liv) was contradictory enabling fire-free outcomes in particular cases, and not in others (Table 5):

PEA*liv*rew*SAN*HEA + PEA*liv*REW*SAN*HEA. This can be further simplified to: PEA*liv*SAN*HEA.

This finding demonstrates that two-step QCA can help to resolve contradictory cases by identifying the proximate conditions that distinguish between uniform remote contexts. It 
shows that fire mitigation in high risk contexts first and foremost requires sanctions, and yet sanction alone does not generate fire-free outcomes. Rather, in the high risk context where peat soil was extensive and livelihood diversity was low, the combined influence of fear of sanction and concern for health created fire-free outcomes. The role of satisfaction with the reward of the programme was less important for the outcome in this context (it is both present and absent across the cases of fire (Lukit) and fire mitigation (KT)), and concern for health alone (i.e. Lukit) did not catalyse a positive fire-free outcome.

Table 6. Truth table for the proximate conditions and PEA*liv - a high fire risk context leading to both fire and fire-free outcomes.

\begin{tabular}{|c|c|c|c|c|c|}
\hline \multirow[b]{2}{*}{ Cases } & \multirow{2}{*}{$\begin{array}{l}\text { Remote conditions } \\
\text { PEA*liv }\end{array}$} & \multicolumn{3}{|c|}{ Proximate } & \multirow[t]{2}{*}{ Outcome } \\
\hline & & REW & $\overline{\text { SAN }}$ & HEA & \\
\hline Peto & 1 & 0 & 1 & 1 & 1 \\
\hline Pela. & 1 & 0 & 1 & 1 & 1 \\
\hline KT & 1 & 1 & 1 & 1 & 1 \\
\hline Lukit & 1 & 0 & 0 & 1 & 0 \\
\hline Dayun & 1 & 1 & 0 & 1 & 0 \\
\hline
\end{tabular}

Figure 2. Remote and proximate conditions for fire-free outcomes in high and low risk contexts. Top panel shows low risk (light grey) contexts: peatland extent is low, livelihood diversity is high, land planted extent is high, sanctions alone are sufficient $\left(\mathrm{PLA}^{*}\right.$ pea*LIV*SAN). Bottom panel shows high risk (dark grey) contexts: peatland is extensive and livelihood diversity is low (planted land extent has no influence), bundles of deterrents are necessary (PEA*liv*SAN*HEA).

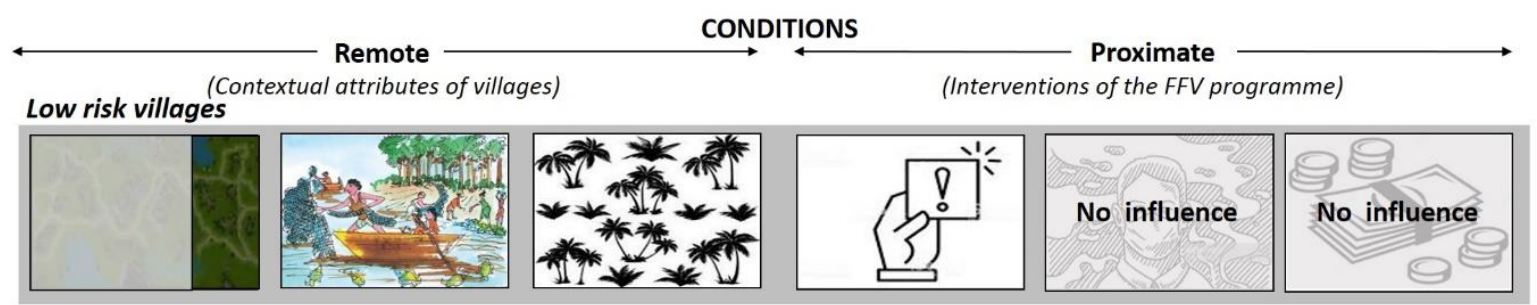

High risk villages

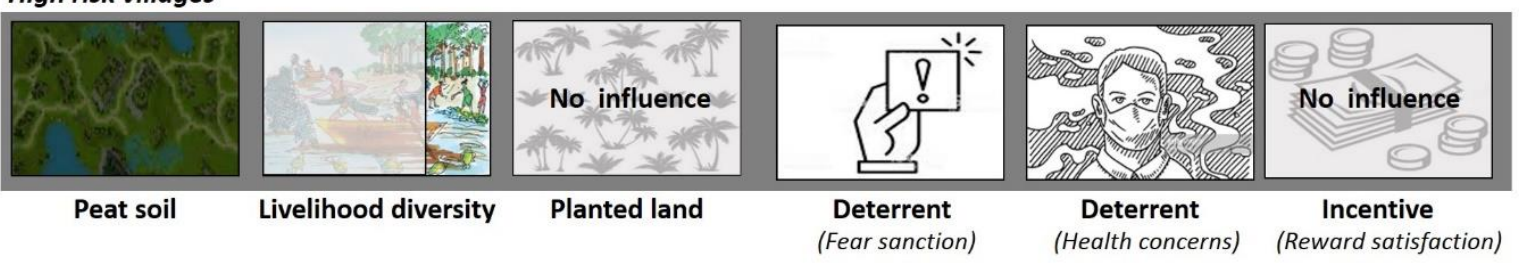

The third configuration (Table 6) of remote conditions (pla*PEA) that enabled fire mitigation by the FFV, was found in combination with the following proximate conditions: pla*PEA*rew*SAN*HEA + pla*PEA*REW*san*HEA.

Simplifying the notation does not resolve the contradictory cases and so brings limited clarity. However, if we concentrate only on the two fire-free cases, the results suggest that the role of concern for health was consistent and the following minimisation applies: pla*PEA*HEA. 
This finding suggests that in some high risk contexts, namely where unplanted lands and peat soils are abundant, awareness about the negative impacts of peat fire on health can generate fire-free outcomes. This condition must be present in combination with at least one other mechanism such as reward satisfaction or the fear of sanction in order to generate fire-free outcomes. However, as mentioned above, this result must be approached with caution and deserves more scrutiny since the second step did not resolve contradictory outcomes in two cases (i.e. KP and Dayun), in these cases the influence of reward satisfaction combined with health concerns was unclear (Table 7). However, we can draw on our case-based knowledge to interpret the difference in outcomes between two villages with somewhat similar conditions. Notably, Dayun (outcome 0) was dealing with a number of tenurial conflicts over a larger village area than KP, and while the leadership in the village had secured additional fire-fighting equipment and was invested in fire control, they were critical of the support from the FFV. To the contrary, in KP the leadership celebrated engagement with the FFV, indeed having been nominated as a local champion and had represented their 'success' personally in discussions in Paris at the UNFCCC COP21.

Table 7. Truth table for the proximate conditions and pla*PEA - a high fire risk context

\begin{tabular}{|l|l|l|l|l|l|}
\hline \multirow{2}{*}{ Cases } & \multirow{2}{*}{$\begin{array}{l}\text { Enabling remote conditions } \\
\text { pla*PEA }\end{array}$} & \multicolumn{2}{|l|}{ Proximate } & \multirow{2}{*}{ Outcome } \\
\cline { 3 - 7 } & & REW & SAN & HEA & \\
\hline Peto & 1 & 0 & 1 & 1 & 1 \\
\hline KP & 1 & 1 & 0 & 1 & 1 \\
\hline Dayun & 1 & 1 & 0 & 1 & 0 \\
\hline Lukit & 1 & 0 & 0 & 1 & 0 \\
\hline Seg & 1 & 0 & 1 & 0 & 0 \\
\hline
\end{tabular}

\section{Discussion}

The results highlighted that incentives were less important than deterrents in shaping environmental outcomes. However, there was also no single pathway to fire-free outcomes, and combinations of interventions were often important, particularly in high fire risk contexts.

\subsection{Deterrents more important than incentives in securing fire-free outcomes}

Incentives provided by the FFV had little impact on scheme outcomes. Rather, communities responded more strongly to the deterrents of sanctions and those related to raising health concerns. Indeed, fear of sanctions was the condition most consistently related to fire-free outcomes. 
The FFV is widely represented as a PES programme, in which the providers are compensated with a reward for avoiding fire use. The reward is strictly conditional on verified performance, which is considered an essential, if rarely used, element of 'idealised' PES design (Wunder et al., 2018). Despite meeting this prerequisite, our data indicated that the FFV reward was not an influential condition for success, neither alone or in combination with other features of the programme. While incentives are often framed as alternatives to enforcement-based approaches, the incentive had little impact over other drivers of behaviour and only combinations of deterrents (i.e. fear of sanctions and concerns for health) were evident in the fire-free cases in our study.

This finding, whilst attesting to the importance of sanctions and deterrent effects for behaviour change, also raises important questions of equity in PES schemes (Pascual et al., 2014). Over-reliance on sanctions shifts the burdens of fire mitigation and behaviour change on to small-scale land managers - some of whom have fewest alternatives and least resilience (Carmenta et al., 2013).

An equitable strategy would likely, independent of the short-term fire outcomes highlighted in this study, still consider measures that afford affected communities access to alternatives for maintaining livelihoods in healthy and fire-free contexts. These may be local alternatives for fire-free livelihoods (e.g. paludiculture) (Wichtmann et al., 2016), and could include alternatives to reduce emigration from provinces and regions that are sources of the immigration to Riau for land exploitation (Jelsma et al., 2017). Previous research has highlighted that programmes that provide such support to small-scale land managers are considered among the most effective, and least controversial of all policy options - a critical consideration in the context of Indonesia's complex political economy (Carmenta et al., 2017). Fire-free interventions must consider the widespread concerns regarding the viability of achieving sustainable land management on peatlands (Evers et al., 2017; Wijedasa et al., 2017). How the responsibilities for providing such programmes should be equitably designed and allocated among different stakeholders (e.g. between the private sector, state, donors) is a challenging question, particularly in the case of transboundary environmental governance (Corbera et al., 2019). Moreover, while local small-scale farmers are the focus of many policy responses to mitigate uncontrolled fires, fire risk in Indonesia results from the actions of multiple agents and drivers, including global environmental change, industrial-scale peat drainage, investment dynamics and consumer preferences (Barlow et al., 2018; Fischer et al., 2012).

The relative ineffectiveness of incentives could also be a function of the specific incentives offered by the FFV. There may be a need to consider alternatives, including 'adaptive rewards', in which adjustments can be made to improve the function as an influential incentive. Options include considering alternative ways of distributing rewards, such as releasing payments at the household level or differentiating payments by livelihood type or type of burden experienced, approaches identified as necessary in other contexts (Newton et al., 2012). Institutional adaptations could be supportive through soliciting reward preferences from constituents. Previous research shows that aligning rewards with the place-based values of participants improves equity and effectiveness (Wunder et al., 2018). Co-creation of 
incentives through participatory research could help to indicate the incentives that would resonate with local constituents and increase the legitimacy, and ultimately the influence and equitability, of the programme. More research is needed to understand why the reward had such minimal influence in the context of the FFV.

\subsection{Combinations of interventions needed, particularly in high risk contexts}

Despite the relative importance of deterrents over incentives, we found that the success of FFV depended on combinations of conditions (conjunctural causation), rather than the influence of any single condition in isolation (Wunder et al., 2018). While initiatives often support simple and targeted interventions focused on specific drivers of change, our results suggested that combinations of interventions were more effective. Thus, the 5-part approach of the FFV was likely appropriate, and reflects earlier calls to avoid simplistic approaches to governing environmental challenges (Ostrom et al., 2007).

However, identifying the appropriate mix of incentives and deterrents (e.g. sanctions, raising local concerns for health) is a central challenge, particularly in contested policy domains (Carmenta et al., 2017; Meijaard and Sheil, 2019). Our results indicated that the landscape context is key to selecting the appropriate mix of interventions. Different combinations of interventions were required for high risk contexts, when compared with low risk contexts. This suggests that targeting interventions bundles to particular landscape contexts might improve the efficiency of future programmes. In the two relatively high fire risk landscapes (i.e. those dominated by peat land and unplanted land), single interventions were insufficient to delivering positive environmental outcomes. While the fear of sanction was important to determining fire-free outcomes (i.e. was present in all of the cases where the FFV mitigated fire), alone this condition was only sufficient in low-risk landscape contexts: those on mineral soils, where residents already had alternative livelihood options, and had already planted large extents of the available land. However, relying on sanctions alone, whilst potentially effective, raises considerable ethical dilemmas that cannot be overlooked. In high risk contexts, fear of sanctions required additional interventions, including deterrents - namely interventions focused on soliciting the concern of residents for their health.

Health concerns was a very important, though insufficient, condition for delivering positive environmental outcomes. When combined with other interventions motivating behaviour change (i.e., incentives, deterrents), soliciting concern for the negative health impacts of smoke exposure was frequently associated with positive outcomes. This finding supports previous research that identified health as a unanimous concern uniting stakeholders with otherwise diverse views on the benefits and burdens of peat fires (Carmenta et al., 2017). It highlights the importance of considering multiple pathways to impact including the potential benefits to shifting the tropical mega-fire discourse: from one framed around illegality, biodiversity loss and carbon emissions (Cochrane, 2003; Huijnen et al., 2016; Turetsky et al., 2015), to one centred on the humanitarian burden of fires (Brondízio et al., 2016). Indeed framing complex challenges as humanitarian problems has resulted in behavioural change in a number of other contexts (Davin, 1982). 
Our findings also suggest ways in which deterrents may be combined with additional interventions that help to shift the landscape context defining fire risk (i.e. remote conditions in our study). For example, the results showed that increasing the proportion of planted land in a given landscape helped to prevent fires; programmes could thus seek to engage interventions to ensure that existing drained peatland is planted (Gingold et al., 2012). However, such programmes require careful assessment because perverse outcomes are also possible (e.g. potential for rebound, increased use of agricultural inputs) (Meijaard and Sheil, 2019; Phalan et al., 2016; Suyanto et al., 2004).

\subsection{Tenure and fire-free alternatives}

A clear burden of the FFV is that it further restricts the use of fire for clearing agricultural land, which is the main income-generating activity in the region (Meijaard and Sheil, 2019). Farmers who lack alternatives to clear land, such as machinery, may face food insecurity and diminished livelihood opportunities. The FFV combination of conditional rewards with interventions such as agricultural support means that, in theory, it could support joint environmental and social goals (Phalan et al., 2016). Indeed, the agricultural support component of the FFV was intended to mitigate land-based livelihood burdens. However, we found that the agricultural support of the programme was not applied due to the chronic land tenure ambiguity in the region.

Tenure conflict contributed to explaining why seemingly similar cases encountered different fire outcomes. Notably the villages of KP and Dayun were an example of this, where land tenure insecurity contributed to the failure of the programme. Elsewhere in the region, tenure ambiguity has created land conflicts and promulgated uncertainties in defining different landholders' attribution for fire (Gaveau et al., 2017), including involving absentee investors who often drive land use change but are geographically removed (Jelsma et al., 2017). Tenure ambiguity could also undermine rewards-based fire-free programmes since absentee landowners likely have no vested interests in FFV outcomes, yet a large influence on land management. This ambiguity is fundamentally disruptive to sustainable resource management, mirroring findings from other contexts (e.g., REDD+), where improved tenure security has been identified as a precondition to success (Cotula and Mayers, 2009). Indeed, PES effectiveness relies on the ability of service providers to keep out third party intruders (Wunder, 2005).

\subsection{Conclusions}

In this study, we evaluated what factors and their combinations worked best to reduce fire extent within a payments for environmental services programme set up to address catastrophic peatland fires in Indonesia. We used QCA to compare the outcomes in 10 villages, distinguishing already existing factors, such as type of soil, from those related to the intervention (rewards, sanctions and health-related awareness). We found that, for villages with higher pre-existing risk of fire (i.e. determined by factors such as soil type), a single intervention fell short of avoiding fire use and a combination worked best. 
A final remark regards how further research can inform upscaling programmes for peat fire mitigation. There is broad recognition that there is no "one-size-fits-all" approach to reconciling environment and development challenges, yet there are also clearly limitations (e.g. high costs, scalability) to tailor-made programmes and their bundles of interventions. Identifying the salient local conditions for change, via methods such as QCA, offers a strategy to balance selecting bundles of generic interventions with local contexts. In this way, our results generate insights for plans to up-scale the FFV nationally (see Sloan et al., 2017). Future programmes should further consider landscape contexts and fire risk variables in their design (i.e. mix of interventions) - including extent of peatland, the proportion of land already planted and availability of alternative livelihoods in the region. With the inclusion of additional factors that are potentially important (e.g. livelihood aspirations, ethnic diversity or tenure security) (Suyanto et al., 2004; Yuliani et al., 2018) intervention bundles could be even more appropriately targeted. Future fire mitigation programmes should invest in identifying incentives that resonate with local constituents to equitably mitigate the burden of fire-free farming, consider the landscape context and how programmes will be affected tenure ambiguity.

\section{Acknowledgements}

This work was funded by the Department for International Development of the UK Government (DFID) under project name: Political Economy of Fire and Haze in Indonesia; Project No. 203034 and the Frank Jackson Foundation. We are grateful to APRIL for their interest in generating an evidence base, and to Bogor Agricultural University for their collaboration, particularly to Meilati Ligardini Mangalla and Efral Derek. We are grateful to the insights shared by colleagues at the University of Riau, particularly to Harris Gunawan and Lulu Zulilaili.

\section{References}

1. Adrianto, H.A., Spracklen, D. V, Arnold, S.R., Sitanggang, I.S., Syaufina, L., 2020. Forest and Land Fires Are Mainly Associated with Deforestation in Riau Province, Indonesia. Remote Sens. 12, 3. https://doi.org/https://doi.org/10.3390/rs12010003

2. Angelsen, A., Kaimowitz, D., 2001. Agricultural technologies and tropical deforestation. https://doi.org/10.1079/9780851994512.0000

3. APRIL, 2017. Fire-Free Village Program Review 2017.

4. Arts, B., de Koning, J., 2017. Community Forest Management: An Assessment and Explanation of its Performance Through QCA. World Dev. 96, 315-325. https://doi.org/10.1016/j.worlddev.2017.03.014

5. Barlow, J., França, F., Gardner, T.A., Hicks, C.C., Lennox, G.D., Berenguer, E., Castello, L., Economo, E.P., Ferreira, J., Guénard, B., Gontijo Leal, C., Isaac, V., Lees, A.C., Parr, C.L., Wilson, S.K., Young, P.J., Graham, N.A.J., 2018. The future of hyperdiverse tropical ecosystems. Nature 559, 517-526. https://doi.org/10.1038/s41586-018-0301-1

6. Basurto, X., 2013. Linking multi-level governance to local common-pool resource theory using fuzzy-set qualitative comparative analysis: Insights from twenty years of biodiversity conservation in Costa Rica. Glob. Environ. Chang. 23, 573-587. https://doi.org/10.1016/j.gloenvcha.2013.02.011 
7. Blom, B., Sunderland, T., Murdiyarso, D., 2010. Getting REDD to work locally: lessons learned from integrated conservation and development projects. Environ. Sci. Policy 13, 164-172. https://doi.org/10.1016/j.envsci.2010.01.002

8. Brockhaus, M., Korhonen-Kurki, K., Sehring, J., Di Gregorio, M., Assembe-Mvondo, S., Babon, A., Bekele, M., Gebara, M.F., Khatri, D.B., Kambire, H., Kengoum, F., Kweka, D., Menton, M., Moeliono, M., Paudel, N.S., Pham, T.T., Resosudarmo, I.A.P., Sitoe, A., Wunder, S., Zida, M., 2017. REDD+, transformational change and the promise of performance-based payments: a qualitative comparative analysis. Clim. Policy 17, 708-730. https://doi.org/10.1080/14693062.2016.1169392

9. Brondízio, E.S., de Lima, A.C.B., Schramski, S., Adams, C., 2016. Social and health dimensions of climate change in the Amazon. Ann. Hum. Biol. 43, 405-414.

10. Carmenta, R., Vermeylen, S., Parry, L., Barlow, J., 2013. Shifting Cultivation and Fire Policy: Insights from the Brazilian Amazon. Hum. Ecol. 41. https://doi.org/10.1007/s10745-013-9600-1

11. Carmenta, R., Zabala, A., Daeli, W., Phelps, J., 2017. Perceptions across scales of governance and the Indonesian peatland fires. Glob. Environ. Chang. 46. https://doi.org/10.1016/j.gloenvcha.2017.08.001

12. Cattau, M.E., Harrison, M.E., Shinyo, I., Tungau, S., Uriarte, M., DeFries, R., 2016. Sources of anthropogenic fire ignitions on the peat-swamp landscape in Kalimantan, Indonesia. Glob. Environ. Chang. 39, 205-219. https://doi.org/https://doi.org/10.1016/j.gloenvcha.2016.05.005

13. Cochrane, M.A., 2003. Fire science for rainforests. Nature 421, 913. https://doi.org/https://doi.org/10.1038/nature01437

14. Cole, L.E.S., Bhagwat, S.A., Willis, K.J., 2019. Fire in the swamp forest: palaeoecological insights into natural and human-induced burning in intact tropical peatlands. Front. For. Glob. Chang. 2, 48.

15. Corbera, E., Busck-Lumholt, L.M., Mempel, F., Rodríguez-Labajos, B., 2019. Environmental Justice in Telecoupling Research, in: Telecoupling. Springer, pp. 213232.

16. Cotula, L., Mayers, J., 2009. Tenure in REDD: Start-point or afterthought? London, UK.

17. Crippa, P., Castruccio, S., Archer-Nicholls, S., Lebron, G.B., Kuwata, M., Thota, A., Sumin, S., Butt, E., Wiedinmyer, C., Spracklen, D. V, 2016. Population exposure to hazardous air quality due to the 2015 fires in Equatorial Asia. Sci. Rep. 6, 37074.

18. Curtis, P.G., Slay, C.M., Harris, N.L., Tyukavina, A., Hansen, M.C., 2018. Classifying drivers of global forest loss. Science (80). 361, 1108 LP - 1111. https://doi.org/10.1126/science.aau3445

19. Davin, A., 1982. Child labour, the working-class family, and domestic ideology in 19th century Britain. Dev. Change 13, 633-652.

20. Defries, R.S., Rudel, T., Uriarte, M., Hansen, M., 2010. Deforestation driven by urban population growth and agricultural trade in the twenty-first century. Nat. Geosci. 3, 178-181. https://doi.org/10.1038/ngeo756

21. Dennis, R.A., Mayer, J., Applegate, G., Chokkalingam, U., Colfer, C.J.P., Kurniawan, I., Lachowski, H., Maus, P., Permana, R.P., Ruchiat, Y., Stolle, F., Suyanto, Tomich, T.P., 2005. Fire, People and Pixels: Linking Social Science and Remote Sensing to Understand Underlying Causes and Impacts of Fires in Indonesia. Hum. Ecol. 33, 465504. https://doi.org/10.1007/s10745-005-5156-Z

22. Duchelle, A.E., Simonet, G., Sunderlin, W.D., Wunder, S., 2018. What is REDD+ achieving on the ground? Curr. Opin. Environ. Sustain. 32, 134-140. https://doi.org/https://doi.org/10.1016/j.cosust.2018.07.001 
23. Evers, S., Yule, C.M., Padfield, R., O’Reilly, P., Varkkey, H., 2017. Keep wetlands wet: the myth of sustainable development of tropical peatlands-implications for policies and management. Glob. Chang. Biol. 23, 534-549.

24. Fischer, J., Dyball, R., Fazey, I., Gross, C., Dovers, S., Ehrlich, P.R., Brulle, R.J., Christensen, C., Borden, R.J., 2012. Human behavior and sustainability. Front. Ecol. Environ. 10, 153-160. https://doi.org/10.1890/110079

25. Gaveau, D., Pirard, R., Salim, M., Tonoto, P., Yaen, H., Parks, S., Carmenta, R., 2017. Overlapping Land Claims Limit the Use of Satellites to Monitor No-Deforestation Commitments and No-Burning Compliance. Conserv. Lett. 10. https://doi.org/10.1111/conl.12256

26. Gaveau, D., Salim, M., Hergoualc'h, K., Locatelli, B., Sloan, S., Wooster, M., Marlier, M., Molidena, E., Yaen, H., Defries, R., Verchot, L., Murdiyarso, D., Nasi, R., Holmgren, P., Sheil, D., 2014. Major atmospheric emissions from peat fires in Southeast Asia during non-drought years: evidence from the 2013 Sumatran fires. Rep. 4, 6112. Sci. Rep. 19. https://doi.org/doi: 10.1038/srep06112.

27. Geist, H.J., Lambin, E.F., 2002. Proximate Causes and Underlying Driving Forces of Tropical Deforestation. Bioscience 52, 143. https://doi.org/10.1641/00063568(2002)052[0143:PCAUDF]2.0.CO;2

28. Gingold, B., Rosenbarger, A., Muliastra, Y., Stolle, F., Sudana, I.M., Manessa, M.D.M., Murdimanto, A., Tiangga, S.B., Madusari, C.C., Douard, P., 2012. How to identify degraded land for sustainable palm oil in Indonesia. World Resour. Inst. Sekala, USA 1-24.

29. Goldstein, J.E., 2016. Knowing the subterranean: Land grabbing, oil palm, and divergent expertise in Indonesia's peat soil. Environ. Plan. A Econ. Sp. 48, 754-770.

30. Grima, N., Singh, S.J., Smetschka, B., Ringhofer, L., 2016. Payment for Ecosystem Services (PES) in Latin America: Analysing the performance of 40 case studies. Ecosyst. Serv. 17, 24-32. https://doi.org/https://doi.org/10.1016/j.ecoser.2015.11.010

31. Hapsari, K.A., Biagioni, S., Jennerjahn, T.C., Reimer, P., Saad, A., Sabiham, S., Behling, H., 2018. Resilience of a peatland in Central Sumatra, Indonesia to past anthropogenic disturbance: Improving conservation and restoration designs using palaeoecology. J. Ecol. 106, 2473-2490.

32. Huijnen, V., Wooster, M.J., Kaiser, J.W., Gaveau, D.L.A., Flemming, J., Parrington, M., Inness, A., Murdiyarso, D., Main, B., van Weele, M., 2016. Fire carbon emissions over maritime southeast Asia in 2015 largest since 1997. Sci. Rep. 6, 26886.

33. Husson, Josse, J., Le, S., Mazet, J., 2018. Multivariate Exploratory Data Analysis and Data Mining.

34. Ide, T., 2015. Why do conflicts over scarce renewable resources turn violent? A qualitative comparative analysis. Glob. Environ. Chang. 33, 61-70. https://doi.org/10.1016/j.gloenvcha.2015.04.008

35. Jefferson, U., Carmenta, R., Daeli, W., Phelps, J., 2020. Characterising policy responses to complex socio-ecological problems: 60 fire management interventions in Indonesian peatlands. Glob. Environ. Chang. 60. https://doi.org/https://doi.org/10.1016/j.gloenvcha.2019.102027

36. Jelsma, I., Schoneveld, G.C., Zoomers, A., Van Westen, A.C.M., 2017. Unpacking Indonesia's independent oil palm smallholders: An actor-disaggregated approach to identifying environmental and social performance challenges. Land use policy 69, 281297.

37. Koplitz, S., Mickley, L.J., Marlier, M.E., Buonocore, J.J., Kim, P.S., Liu, T., Sulprizio, M.P., DeFries, R.S., Jacob, D.J., Schwartz, J., 2016. Public health impacts of the severe haze in Equatorial Asia in September-October 2015: demonstration of a new 
framework for informing fire management strategies to reduce downwind smoke exposure. Environ. Res. Lett. 11.

38. Korhonen-Kurki, K., Sehring, J., Brockhaus, M., Di Gregorio, M., 2013. Enabling factors for establishing REDD+ in a context of weak governance. Clim. Policy 14, 167186. https://doi.org/10.1080/14693062.2014.852022

39. Manzo, K., Padfield, R., Varkkey, H., 2019. Envisioning tropical environments: Representations of peatlands in Malaysian media. Environ. Plan. E Nat. Sp. 2514848619880895.

40. Martin, D.A., 2019. Science of the Total Environment Linking fi re and the United Nations Sustainable Development Goals. Sci. Total Environ. 662, 547-558. https://doi.org/10.1016/j.scitotenv.2018.12.393

41. Marx, A., Rihoux, B., Ragin, C., 2014. The origins, development, and application of Qualitative Comparative Analysis: the first 25 years. Eur. Polit. Sci. Rev. 6, 115-142. https://doi.org/DOI: 10.1017/S1755773912000318

42. Medin, D., Ross, N., Cox, D., 2006. Culture and resource conflict: why meanings matter. Russell Sage Foundation, New York, US.

43. Meijaard, E., Sheil, D., 2019. The Moral Minefield of Ethical Oil Palm and Sustainable Development . Front. For. Glob. Chang. .

44. Miettinen, J., Shi, C., Liew, S.C., 2016. Land cover distribution in the peatlands of Peninsular Malaysia, Sumatra and Borneo in 2015 with changes since 1990. Glob. Ecol. Conserv. 6, 67-78. https://doi.org/https://doi.org/10.1016/j.gecco.2016.02.004

45. Newton, P., Nichols, E.S., Endo, W., Peres, C.A., 2012. Consequences of actor level livelihood heterogeneity for additionality in a tropical forest payment for environmental services programme with an undifferentiated reward structure. Glob. Environ. Chang. 22, 127-136.

46. Oldekop, J.A., Holmes, G., Harris, W.E., Evans, K.L., 2016. A global assessment of the social and conservation outcomes of protected areas. Conserv. Biol. 30, 133-141. https://doi.org/10.1111/cobi.12568

47. Ostrom, E., Janssen, M.A., Anderies, J.M., 2007. Going beyond panaceas. Proc. Natl. Acad. Sci. 104, 15176-15178. https://doi.org/10.1073/pnas.0701886104

48. Pascual, U., Phelps, J., Garmendia, E., Brown, K., Corbera, E., Martin, A., GomezBaggethun, E., Muradian, R., 2014. Social equity matters in payments for ecosystem services. Bioscience 64, 1027-1036.

49. Persoon, G.A., Simarmata, R., 2014. Undoing 'marginality': The islands of the Mahakam Delta, East Kalimantan (Indonesia). J. Mar. Isl. Cult. 3, 43-53. https://doi.org/https://doi.org/10.1016/j.imic.2014.11.002

50. Phalan, B., Green, R.E., Dicks, L. V., Dotta, G., Feniuk, C., Lamb, A., Strassburg, B.B.N., Williams, D.R., Ermgassen, E.K.H.J.Z., Balmford, A., 2016. How can higheryield farming help to spare nature? Science (80-. ). 351, 450-451. https://doi.org/10.1126/science.aad0055

51. Ragin, C.C., 1987. The Comparative Method. University of California Press.

52. Rihoux, B., 2003. Bridging the Gap between the Qualitative and Quantitative Worlds? A Retrospective and Prospective View on Qualitative Comparative Analysis. Field methods 15, 351-365. https://doi.org/10.1177/1525822x03257690

53. Schneider, C., Wagemann, C., 2012. Set-theoretic methods for the social sciences: A guide to qualitative comparative analysis. Cambridge University Press, New York, US.

54. Schneider, C.Q., Wagemann, C., 2006. Reducing complexity in Qualitative Comparative Analysis (QCA): Remote and proximate factors and the consolidation of democracy. Eur. J. Polit. Res. 45, 751-786. https://doi.org/10.1111/j.14756765.2006.00635.x 
55. Sehring, J., Korhonen-Kurki, K., Brockhaus, M., 2013. Qualitative Comparative Analysis (QCA) An application to compare national REDD+ policy processes. Bogor.

56. Sloan, S., Locatelli, B., Wooster, M.J., Gaveau, D.L.A., 2017. Fire activity in Borneo driven by industrial land conversion and drought during El Niño periods, 1982-2010. Glob. Environ. Chang. 47, 95-109. https://doi.org/10.1016/J.GLOENVCHA.2017.10.001

57. Suyanto, S., Applegate, G., Permana, R.P., Khususiyah, N., Kurniawan, I., 2004. The role of fire in changing land use and livelihoods in Riau-Sumatra. Ecol. Soc. 9.

58. Tacconi, L., 2016. Preventing fires and haze in Southeast Asia. Nat. Clim. Chang. 6, 640-643. https://doi.org/doi:10.1038/nclimate3008

59. Tan-Soo, J.-S., Pattanayak, S.K., 2019. Seeking natural capital projects: Forest fires, haze, and early-life exposure in Indonesia. Proc. Natl. Acad. Sci. 116, 5239 LP - 5245. https://doi.org/10.1073/pnas.1802876116

60. Travers, H., Clements, T., Milner-Gulland, E.J., 2016. Predicting responses to conservation interventions through scenarios: A Cambodian case study. Biol. Conserv. 204, 403-410. https://doi.org/https://doi.org/10.1016/j.biocon.2016.10.040

61. Turetsky, M., Benscoter, B., Page, S., Rein, G., Van Der Werf, G., Watts, A., 2015. Global vulnerability of peatlands to fire and carbon loss. Nat. Geosci. 8, 11-14.

62. Varkkey, H., 2016. The Haze Problem in Southeast Asia. Routledge, London. https://doi.org/https://doi.org/10.4324/9781315717814

63. Wichtmann, W., Schröder, C., Joosten, H., 2016. Paludiculture-productive use of wet peatlands.

64. Wiggins, E.B., Czimczik, C.I., Santos, G.M., Chen, Y., Xu, X., Holden, S.R., Randerson, J.T., Harvey, C.F., Kai, F.M., Liya, E.Y., 2018. Smoke radiocarbon measurements from Indonesian fires provide evidence for burning of millennia-aged peat. Proc. Natl. Acad. Sci. 115, 12419-12424.

65. Wijedasa, L.S., Jauhiainen, J., Könönen, M., Lampela, M., Vasander, H., Leblanc, M.C., Evers, S., Smith, T.E.L., Yule, C.M., Varkkey, H., Lupascu, M., Parish, F., Singleton, I., Clements, G.R., Aziz, S.A., Harrison, M.E., Cheyne, S., Anshari, G.Z., Meijaard, E., Goldstein, J.E., Waldron, S., Hergoualc'h, K., Dommain, R., Frolking, S., Evans, C.D., Posa, M.R.C., Glaser, P.H., Suryadiputra, N., Lubis, R., Santika, T., Padfield, R., Kurnianto, S., Hadisiswoyo, P., Lim, T.W., Page, S.E., Gauci, V., Van Der Meer, P.J., Buckland, H., Garnier, F., Samuel, M.K., Choo, L.N.L.K., O’Reilly, P., Warren, M., Suksuwan, S., Sumarga, E., Jain, A., Laurance, W.F., Couwenberg, J., Joosten, H., Vernimmen, R., Hooijer, A., Malins, C., Cochrane, M.A., Perumal, B., Siegert, F., Peh, K.S.-H., Comeau, L.-P., Verchot, L., Harvey, C.F., Cobb, A., Jaafar, Z., Wösten, H., Manuri, S., Müller, M., Giesen, W., Phelps, J., Yong, D.L., Silvius, M., Wedeux, B.M.M., Hoyt, A., Osaki, M., Hirano, T., Takahashi, H., Kohyama, T.S., Haraguchi, A., Nugroho, N.P., Coomes, D.A., Quoi, L.P., Dohong, A., Gunawan, H., Gaveau, D.L.A., Langner, A., Lim, F.K.S., Edwards, D.P., Giam, X., Van Der Werf, G., Carmenta, R., Verwer, C.C., Gibson, L., Gandois, L., Graham, L.L.B., Regalino, J., Wich, S.A., Rieley, J., Kettridge, N., Brown, C., Pirard, R., Moore, S., Capilla, B.R., Ballhorn, U., Ho, H.C., Hoscilo, A., Lohberger, S., Evans, T.A., Yulianti, N., Blackham, G., Onrizal, Husson, S., Murdiyarso, D., Pangala, S., Cole, L.E.S., Tacconi, L., Segah, H., Tonoto, P., Lee, J.S.H., Schmilewski, G., Wulffraat, S., Putra, E.I., Cattau, M.E., Clymo, R.S., Morrison, R., Mujahid, A., Miettinen, J., Liew, S.C., Valpola, S., Wilson, D., D’Arcy, L., Gerding, M., Sundari, S., Thornton, S.A., Kalisz, B., Chapman, S.J., Su, A.S.M., Basuki, I., Itoh, M., Traeholt, C., Sloan, S., Sayok, A.K., Andersen, R., 2017. Denial of long-term issues with agriculture on tropical peatlands will have devastating consequences. Glob. Chang. Biol. 23. 
https://doi.org/10.1111/gcb.13516

66. Wooster, J.M., Gaveau, L.D., Salim, A.M., Zhang, T., Xu, W., Green, C.D., Huijnen, V., Murdiyarso, D., Gunawan, D., Borchard, N., Schirrmann, M., Main, B., Sepriando, A., 2018. New Tropical Peatland Gas and Particulate Emissions Factors Indicate 2015 Indonesian Fires Released Far More Particulate Matter (but Less Methane) than Current Inventories Imply. Remote Sens. https://doi.org/10.3390/rs10040495

67. Wunder, S., 2005. Payments for environmental services: some nuts and bolts. CIFOR, Bogor, Indonesia

68. Wunder, S., Brouwer, R., Engel, S., Ezzine-de-Blas, D., Muradian, R., Pascual, U., Pinto, R., 2018. From principles to practice in paying for nature's services. Nat. Sustain. 1, 145-150. https://doi.org/10.1038/s41893-018-0036-X

69. Yuliani, E.L., de Jong, E.B.P., Knippenberg, L.W.J., Bakara, D.O., Salim, M.A., Sunderland, T., 2018. Keeping the land: Indigenous communities struggle over land use and sustainable forest management in Kalimantan, Indonesia. Ecol. Soc. 23, DOI https://doi.org/10.5751/ES-10640-230449 